\title{
Using Curriculum Deliberation to Address Controversial Issues: Developing Holocaust Education Curriculum For Latvian SchOOlS
}

\author{
THOMAS Misco \\ Miami University
}

\begin{abstract}
This paper explores how a cross-cultural project responded to the need for new Holocaust educational materials for the Republic of Latvia through the method of curriculum deliberation. Analysis of interview, observational, and document data drawn from seven curriculum writers and numerous project members suggest that curriculum deliberation helped awaken a controversial and silenced history while attending to a wide range of needs and concerns for a variety of stakeholders. The findings highlight structural features that empowered the curriculum writers as they engaged in protracted rumination, reflected upon competing norms, and considered the nuances of the curriculum problem in relation to implementation. Understanding the process, challenges, and promises of cross-cultural curriculum deliberation holds significance for educators, curricularists, and educational researchers wishing to advance teaching and learning within silenced histories and controversial issues.
\end{abstract}

Misco, T. (2007). Using curriculum deliberation to address controversial issues: Developing Holocaust education curriculum for Latvian schools. International Journal of Education Policy and Leadership 2(7). Retrieved [DATE] from http://www.ijepl.org.

\section{Introduction}

Since Schwab (1970) declared the field of curriculum moribund, the use of curriculum deliberation as a method of curricular change has sporadically come into favor. Yet, since Schwab's declaration, few empirical studies have inquired into the promise and potential of deliberation in action (Atkins, 1990; Silva, 2000), and none has examined the use of deliberation in a cross-cultural setting. Curriculum building through deliberation may often be misunderstood (Schwab, 1975; Shaw, 1975), yet this technique is one of the most promising ways to confront practical problems and controversial issues. Studies on deliberations are important (Mulder, 1991), for only a growing body of descriptions can allow the field to consider suggestions for future deliberations or theoretical advancement. This critical research issue is doubly important when deliberation is applied to educational problems and when diverse stakeholders are privileged.

This article addresses the problem of limited Holocaust education in Latvia and how a team of curriculum writers produced educational materials in response to this need. I begin by placing this project within the context of teaching about controversial issues, which is an educational imperative in a socially just and democratic society. I then provide an overview of the curricular problem, as well as the immediate context and research methods, and a synopsis of curriculum deliberation. Finally, I address some of the themes that emerged from this experience, which include the promises and challenges of curriculum deliberation in a cross-cultural setting.

\section{Controversial Issues in Democratic Education}

Democratic societies require citizens who can make judgments about controversial issues (Engle \& Ochoa, 1988). These judgments and discussions, which often involve contemporary public concerns, pay a democratic dividend by increasing civic efficacy, critical thinking skills, interpersonal skills, and participation in political activity, as well as elevating interest in current events, social studies, social issues, and the development of tolerance (Harwood \& Hahn, 1990). Yet, controversial topics often receive little attention in schools, as teachers sometimes avoid addressing the belief systems of their culture and society (Evans, Avery, \&

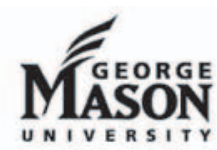


Pederson, 2000). Education in a democracy requires preparing citizens to rationally deliberate and reflect on controversial issues, which very often reflect deeply embedded values and beliefs (LaCapra, 1992; Parker, 2003; Ross \& Marker, 2005). Students in a democracy need to uncover and examine how these values and standards originated and are perpetuated (Griffin, 1942/1996).

Similar to most controversial issues, historical memory is situated within unique sociocultural conditions, and in some cases, memory of the Holocaust constitutes the critical historical issue (Simon, 2000). At issue is the extent and degree to which the attention of citizens is directed toward or away from examining and understanding Holocaust history (LaCapra, 1992). Because Holocaust memory contains an ethical responsibility, all individuals within these societies form some degree of moral relationship with the past, which involves articulating and renegotiating Holocaust representation and pedagogy (Baum, 2000). Therefore, the representation of history in education changes over time as the particular culture or society re-creates different relationships with its past.

One country currently involved in renegotiating its past is the Republic of Latvia. As Latvians continue to develop their democratic way of life after centuries of occupation, decisions are constantly made about the Latvian narrative and which historical and civic knowledge, skills, and dispositions are most worthy. Some of these decisions pertain generally to the Holocaust and others are particular to the Holocaust in Latvia. Given the beneficial collateral effects of addressing closed areas, controversial topics, and Holocaust history, any curricular efforts aimed at advancing these issues in any society, including Latvia, demand the attention of social studies educators, educational researchers, and curricularists.

\section{Statement of the Problem}

The Nazi occupation of Latvia during World War II resulted in a series of horrific events for thousands of Jews and minorities in Latvia. During this time, many Latvians made an array of choices in response to this occupation. Some Latvians chose to collaborate with the Nazis, others engaged in the rescue of Jews, and the great majority chose to acquiesce and act as bystanders. But following the Soviet reoccupation of Latvia in 1945, Latvian schools rarely addressed the topic of the Holocaust, including the array of choices available and the ultimate murder of Jews. After Latvia regained independence in 1991, teaching about the Holocaust as it occurred in Latvia remained a rarity due to the hesitancy many teachers had when addressing this sensitive topic, given the large number of living bystanders and collaborators, a lack of political encouragement, and a crowded public school curriculum. Consequently, Latvia's minimal curricular devotion to the Holocaust and Latvia's involvement in it (Latvian Ministry of Education, 2004) posed the problem at the center of this study.

Early in 2004, a series of grant awards culminated in the partnership of Latvian curriculum writers, professors from Latvia and the United States, Holocaust historians, and teacher educators to develop a new Holocaust curriculum for Latvian schools. Although some Holocaust curriculum resources were already available to Latvian teachers, few chose to implement those lessons. As a result of this absence, these grant awards led to a project that attempted to respond to the need for a meaningful treatment of the Holocaust that not only addressed the Latvian experience but also invited enactment and efficacy. This project responded to Latvia's Holocaust history by creating new curricula that take into account the aforementioned influences that served to silence Holocaust history in Latvian schools.

The curriculum development project included six phases in the United States and the Republic of Latvia. Phase one included meetings of faculty and personnel from a university in the midwestern United States, the Latvian Ministry of Education, the United States Embassy, and the University of Latvia in Riga. These meetings set the foundation and aims of the project, organized funding arrangements, and outlined logistical operations. The second phase of the project commenced with the arrival of seven curriculum writers for a two-week stay in the United States. The first week of this phase included an orientation and negotiation of the goals and objectives of the project, and the second week was spent at the United States Holocaust Memorial Museum (USHMM) in Washington, D.C. Following the week at the USHMM, the curriculum writing team returned to Latvia to collect relevant historical materials for the eventual development of the new curriculum.

The project's third phase entailed a six-week residency experience in the United States. After the bulk of the writing was complete and the writers had returned to Latvia, the lesson plans underwent an editing and translation process in advance of a national field test. Phase four included extensive field testing of the curriculum across lines of ethnicity, geography, and socioeconomic status. The fifth phase included a national conference in Riga, the capital of Latvia, to inaugurate the materials and raise the awareness of their availability and effectiveness. The sixth and final phase contained teacher training workshops that involved a number of the project's curriculum writers and teachers from each educational district in Latvia. 
Throughout these six phases, the structure of the project closely approximated the method of curriculum deliberation.

\section{Curriculum Deliberation}

As the author of the landmark "Practical" papers, Schwab (1970, 1971, 1973, 1983) set forth a conception of deliberation that is complex and arduous and involves the recurring interdependency of both means and ends. According to Schwab (1970), deliberation must seek out alternative solutions, consider the potential consequences of each alternative, weigh the consequences against each other, and choose "not the right alternative, for there is no such thing, but the best one" (p. 319).

Harris (1986) suggested that deliberation is the "weighing and examining of the reasons for and against a measure, and giving careful consideration and mature reflection to choices; it often involves considered action by a group of persons" (p. 117), which is suggestive of the interpenetration of experiences, evidence, and reflection recurrent in much of John Dewey's work. In addition, McCutcheon (1995) noted that deliberation is not simply adjusting to a problem and ignoring antecedent and underlying circumstances. Rather, it is a process of "reasoning about practical problems. It is solution oriented, that is, toward deciding on a course of action" (p. 4). The business of deliberation involves conceiving the problem, weighing resolutions, creating alternatives, engaging in discourse, and thinking reflectively in a nonlinear process. As interests collide during group deliberation, knowledge is socially constructed. The differing interests within and between individuals are rationally debated, and this democratic process pays a dividend as a positive solution is chosen.

Rich dialogue and discussion within deliberation should lead to a phase of negotiation and consensus building. Deliberation involves compromise and deference, as well as the ability to relinquish individual preferences and interests in some situations (Cohen, 1999). Because it is common for people to treat their own values as if they were well examined and ignore contrary values that others espouse, deliberators must become wary of the "arrogance of specialism" (Schwab, 1973, p. 381), for this is ruinous for defensible solutions. Therefore, skills and attitudes such as compromise and humility are required when competing normative interests of multiple people are brought to the surface, given the resultant conflict stemming from beliefs, attitudes, and understandings that must be reconciled (McCutcheon, 1995).

Given the need for reason, dialogue, weighing of norms, and compromise, deliberation can be understood as the social manifestation of reflective thought, as well as a rehearsal of decision making and action. Similar to reflective thinking (Dewey, 1933), deliberation does not take a linear route from formulating problems to discussing and deciding. Rather, it is a "spiral discovery of meanings" (Roby, 1985, p. 29) that contains critical reflection, backtracking, reviewing, revising, and rejecting (Bonser \& Grundy, 1988). As a result, deliberation involves a responsibility to reject, after proper rumination, what is not judicious, even if it is the solution one might have originally wanted to subscribe to. A sense of responsibility also exists when the disciplined identification of "all those who would be affected by a decision to act, or who constitute important sources of knowledge relating to the problematic situation" (Reid, 1999, p. 58) is considered and where the action is for their benefit.

Although the sequence of deliberation is inherently nonlinear, there are necessary attributes of the reflection occurring within it. Schwab (1971), Roby (1985), and Reid (1999) have all articulated recommended components, which, when synthesized, suggest that deliberation ought to include: assignment of meaning to details in the problem, formulation of meaningful details into discrete problems, weighing and choosing among problem formulations, recursive search of data and possible solutions, rehearsal of the consequences of a chosen solution, weighing of the alternatives and choosing a solution, termination of deliberation and enactment of a tentative solution, and fashioning the roles of the deliberators. A necessary component for optimal discovery of alternatives and solutions implied in this list is diversity. Without diverse opinions, experiences, and suggestions, the deliberative process ceases and fails to create satisfactory solutions.

The main work of curriculum deliberation involves what Schwab (1973) called the "juxtaposition of incommensurables" (p. 383). Values associated with students, teachers, subject matter, and the milieu, what Schwab (1973) referred to as commonplaces, are continually set aside and returned to through the evaluation and revaluation of incompatible ideas concerning what should be done to resolve the curricular problem. Parker (2003) likened the conclusion of this process to "forging together the alternatives and making a decision" (p. 105). Dewey (1922) described it as a problem of wanting "things that are incompatible with one another; therefore, we have to make a choice of what we really want" (p. 134). In group deliberations - where part of the judgment, choice, and action concern what people value - the problems of making and exercising judgments are magnified (Reid, 1999). To complicate matters, the proper representation of fragmented interests can be viewed as a distillation of public interests that 
inform the resolution to curriculum problems, and this convergence should find resonance with the ultimate choices and actions decided upon. Choice and action represent a final phase in the deliberative process but not finality, which is illusory given the tentative nature of decisions concerning practical problems. New data, evidence, and changes in reality or commonplaces might, quite quickly, demand a reconceptualization of the problem and command renewed deliberations.

Just as a number of habits aid in experiencing successful deliberation, there are also those that impede it. Roby (1985) has suggested three main habits that can bedevil the deliberative method: a rush to solution, crisis consciousness, and utopian anticipation (p. 21). Other habits include the externalization of a problematic situation, excluding or giving short shrift to commonplaces, dualistic thinking, uncooperative approaches, an expectation of a linear progression, and intolerance for ambiguity (Roby, 1985). Dewey (1922) presaged many of these habits, which he called "vices of reflection" (p. 137), including being rushed, ignoring responsibilities, not looking far enough ahead, and acting on impulse.

But can the features of curriculum deliberation be applied to practical problems in nascent democracies? Parker (2003) claimed that the prospect of a lively deliberative spirit is extremely problematic in societies where power influences participation in, and the topics considered appropriate for, deliberation. Newly democratic societies that seek to resolve practical curriculum problems might, therefore, find difficulty in engaging in this most democratic experience. Many of these societies contain vestiges of reticence and power inherited from former rule that can undermine constructive deliberation. But if possible, the examination of topics heretofore closed to rational and reflective consideration can work to enable future deliberations and more democratic approaches to other practical problems. Opening problems up to this method would then require the marshaling of diverse and divergent ideas on the particular problem. Although it may be tempting to recruit similar views in the hope of reaching agreement expeditiously, not seeking and utilizing diverse views can result in unworkable solutions ignorant of stakeholders.

\section{Methodology}

This was an ethnographic case study of decisions curriculum writers, curriculum leaders, historians, and institutional agents made within a project attempting to resolve an illstructured curriculum problem. My primary interest was in a problem containing norms, structures, conditions, and processes, which suggested the use of long-term ethno- graphic study (Glaser \& Strauss, 1967). Ethnographic studies are fundamentally interested in cultural context, including the history of the community and the attitudes of community members, parents, educators, citizens, policymakers, and students (Merriam, 2001). Cultural context also involves shared beliefs, values, attitudes, and behavior patterns that inform what is and what should be (Patton, 1990). Given this combination of normative interests, I found an ethnographic case study to be supremely well positioned to seek out socially and culturally constructed meanings of educational commonplaces that Schwab (1973) noted, including students, teachers, subject matter, and the varying voices in the milieu.

As an atypical case, this study was fundamentally interested in how curriculum writers responded to cultural context, societal history, and the attitudes of community members. During field research, I conducted six interviews with each of the seven curriculum writers over the course of the project. I also interviewed U.S. Embassy personnel, Latvian historians, and Latvian teachers. In addition to interview data, my role of research participant provided access to collect a wide breadth of observational field notes during the project meetings. I also collected and analyzed the documents that helped inform the writers' responses to the curriculum problem, as well as each iteration of their new materials.

Given the particular nature of the research setting and problem, the selection of participants constituted an intrinsic and unique case sample, as the intention of the research study was to learn from "highly unusual manifestations of the phenomenon of interest" (Miles \& Huberman, 1994, p. 28). The selection was also criterion based, as I sought to choose individuals based on characteristics that matched the research problem, which in this case involved a particular curriculum development project and the multifarious influences on the writers as they shaped, directed, and influenced the final product.

Selection of participants was also an example of unique case selection, which is not replicable (LeCompte $\&$ Schensul, 1999), does not require the casting of a wide net for possible respondents (Fetterman, 1998), and is inimical to notions of randomness (Wolcott, 1999). Hammersley and Atkinson (1995) suggested that decisions about participants are recurring and usually include a range of individuals, many of whom will require multiple interviews or observations. Although few guidelines exist concerning sample size in qualitative research, Patton (1990) suggested seeking out purposeful samples that yield "informationrich cases" (p. 169), are responsive to the research purpose, yield credibility, and are realistic in terms of time and 
resources. To that end, Amalija, Darva, Irina, Jonco, Jana, Dagnija, and Klaudija are pseudonyms for the Latvian educators whom I interviewed and observed over the course of 18 months.

\section{Writing New Holocaust Curriculum}

Schwab (1983) noted that when curriculum problems are subjected to group deliberation, the question of "who is to do it?" ultimately arises. Given the fundamental obligation of group deliberators, which is to humbly listen to alternative considerations and interests as they relate to the problem's resolution (Schwab, 1970), curriculum deliberation calls for open-minded individuals. In addition, the "first answer to the question of who should be a member of the group is the teacher. Again, and louder: THE TEACHER" (Schwab, 1983, p. 245). The kinds of teachers Schwab recommended are intelligent problems solvers, and not all teacher-writers need to be future users of the curriculum. He also suggested including a principal, a school board member, a community member, and a student as members of the curriculum group.

Because group representation should mirror the educational commonplaces of the students, teachers, subject matter, and individuals within the milieu, examining the membership of the project aided in determining the extent to which the team deviated from the sense of group deliberation Schwab and others envisaged. Given the project's duration, as well as its cross-cultural nature, the codirectors could not recruit student representatives. The project retained subject specialists from the United States, Latvia, Israel, and Sweden, as well as curriculum specialists from throughout Latvia and the United States, to serve as occasional project members. The project also included two curriculum specialists who also served as chairpersons. Finally, the diversity of the writing team, including former administrators, teacher trainers, nongovernmental organization personnel, members of the Latvian History Teachers Association, and teachers with strong relations with the Ministry of Education, allowed for variance of representation from different corners of the milieu.

The initial phase of curriculum deliberation should emphasize commonplaces as writers become familiar with one another and become aware of one another's values and intentions (Schwab, 1973). By uprooting recondite values and interests, including a tendency to avoid the topic, normative beliefs, and commonplace foci, each of the writers was able to consider different situations and review the curricular problem through different commonplace lenses, which Schwab (1971) referred to as "polyfocal conspectus" (p. 356). During the first phase of the project, one writer expressed her desire to focus on "the whole society, not just the school. We have to educate the society also." She suggested the difficulties in transforming society through the school because "they reject everything in the schools. The teacher is the enemy of the public; this is heritage of the Soviet time, where the teacher is in charge of everything." Moreover, she felt that the situation "is so bad in Latvia with social life, economics, and the teachers are responsible for everything, or so people think." Yet, if the implementation of new curricula was to happen, then classroom teachers needed to be honored and valued as deliberators (Silva, 2000), as well as have opportunities to engage in thoughtful consideration of other teachers in their society. The curriculum writers ultimately considered students, historians, the Ministry of Education, parents, politicians, and others when making their curriculum decisions, but they predominately focused on the teacher commonplace.

Schwab (1973) warned that "it is possible for the representative who knows the teaching group to urge conformity of the curriculum to what teachers currently can and are willing to do" (p. 368). Schwab's tocsin represented a real threat for the project, specifically in terms of the degree to which the curriculum would advance Latvian conversation about the Holocaust, given the traditional reticence. Most of the writers certainly had a refined knowledge base of what teachers are currently willing to do, but the writers also sought to advance the pedagogical development of Latvian teachers while simultaneously offering new content. Because social studies teachers prefer to teach what they know and because teachers are often greatly influenced by the cultures of their schools (Marker \& Mehlinger, 1992), the writers sought to increase teachers' knowledge and understanding of the Holocaust in Latvia, while attending to the cultural pressure to avoid the topic. Given the easier alternative of simply turning away from the horror, pain, and questions that come about when confronted with Holocaust history (Totten \& Feinberg, 1995), the writers consciously considered this obstacle when thinking about Latvian teachers. They also took into account the interests and restrictions of time, flexibility of lessons, teachers' fear of the subject matter, residual effects of Soviet rule, and innovative methods, all with an eye toward different teachers situated in different contexts. By distancing themselves from the vagaries of their society through participation in a cross-cultural forum, the writers were able to reflect upon and consider teachers and the implementation of the curriculum through a rehearsal of consequences.

The cross-cultural structure of the project also allowed for protracted reflection and consideration of the problem. 
For example, national exams, infrequent class meetings, brevity of preparatory time, and other systemic forces limit the amount of time Latvian teachers can devote to any given topic. Because all of the writers were aware of structural limitations, which ultimately confound change, these challenges helped to shape how they would write the curriculum as they considered the situation through a different perspective. Jana, one of the curriculum writers, concluded that she spends a great deal more time on the Holocaust than other teachers. Typically she only has "ten hours for World War II, including Latvia during this period, and I speak of Holocaust for four hours," and "in other schools it's maybe nothing." Given this restriction, the writers decided to produce self-contained, modular lessons so that teachers could choose which of the lessons they wanted to teach. They also wrote on a wide range of topics, with the intention of providing teachers with choices in terms of both different content and the degree of focus on the Holocaust in Latvia. At one point, another writer, Irina, reminded the group, "we have to keep in mind that teachers will use these lessons separately." When Irina crafted her lessons, she:

Really thought about teachers and what they wanted and what they would use. One of the biggest issues is time; how to put all these interesting things in [given the limited] time. How to do this in 40 minutes? Also, how to optimize these things and make them in a way that teachers would use?

Another writer, Dagnija, also recognized the reality of limited time and thought that "even if teachers don't use them, they can read them and understand the event" and therefore, at a minimum, become versed in the history should the opportunity to teach the Holocaust present itself.

\section{Flexible Lessons}

One of the ways that the writers deliberatively responded to the influence of time on Holocaust education was by deciding to make flexible lessons as part of their envisioning of the end view of lesson enactment within Latvian classrooms. Diversity within curriculum is desirable so that the curriculum is responsive to the unique needs and resources of the recipients of the materials (Schwab, 1983). Given the unlikely transferability of a "right lesson" for each Latvian history or social studies teacher, the curriculum specialists and writers stressed the need to design materials that allow teachers to exercise judgment and breathe life into goals and objectives through instructional decisions informed by the differences among their students and community. In short, the project team sought to achieve the del- icate balance between affording too much teacher judgment and creating rigid lessons that would inhibit instructional authority.

At the beginning of the deliberative process, Jana felt that the materials would be different from earlier attempts to increase Holocaust education. Due to the inclusion of a variety of political cartoons, films, perspectives, and documents, she thought that "teachers would be able to choose. It's up to the teacher!" By retaining flexibility and choice, Jana concluded that the amount of instructional time on the Holocaust might be increased, at least in high schools, through implementation in political science and civics classes.

Irina was also keenly aware of how the "topic is difficult for educators in Latvia," and, as a result, teachers often claim to not have enough time to teach it. She stressed the need to "show teachers that use this product that it is a possibility for them, not a threat." Irina felt that the writing team could accomplish this goal by emphasizing:

[W] hat will be exciting for them and useful for them. As I work as a teacher trainer I know all these questions about timing and about formal responsibilities, exams, school administration, and so on ... I try to imagine how arguments for teaching and each topic and if I can argue the usefulness of this topic.

In order to make the lessons more inviting for teachers, the team offered flexibility in the lesson choices, topics, and procedures. In all, the team wrote 18 lessons for middle schools and 16 for high schools. Rather than crafting lessons that would appear mandatory or as universal best practices to encourage enactment (Deckert-Peaceman, 2003), project lessons chose to honor the professionalism of teachers and provide substantive choices.

\section{Teachers' Fear of the Content}

Given the deep historical investigations of the Holocaust during their week at the United States Holocaust Memorial Museum (USHMM), the writers reconsidered the default response of avoiding the topic of the Holocaust in Latvia. In general, curriculum deliberation must consider whether teachers are ready to teach the topic, if materials can be devised for them to teach it, and what would happen if those decisions and selections were realized (Schwab, 1983). The curriculum writers attended to these admonitions and sought to create a curriculum that would "show teachers from Latvia how we can do it," in terms of both content and methodology. Because curriculum projects in the past resulted in teachers "not bothering to open" the materials, the writers sought to invest a great deal of 
thought and effort in properly framing and situating the topic of the Holocaust in Latvia. One writer suggested that curriculum projects of the past produced materials focused on "who murdered who, how many, and how awful." Therefore, Amalija noted, "if we manage to talk about conceptual and philosophical ideas, they won't be afraid to talk about the Latvian cases." In addition, Amalija felt that the "starting point [of the Holocaust] needs to be changed for teacher buy-in" so that the important context of Soviet occupation during 1940-41, which shaped the Latvian response to the Nazi occupation, would not be ignored. Irina also suggested the use of "provocative titles and lessons that are catchy; this will help encourage interest and perhaps puzzle. If the Holocaust is one word, that is not enough for getting teachers interested."

Another writer, Klaudija, expressed an additional aim of the writers. She felt the need to not "show Latvians in a bad way; we will be speaking about the people that helped as well," which would foster teacher willingness to explore the lessons and the actual history. Amalija indicated that because historians have worked to make the Holocaust in Latvia well-documented history, it became "more or less clear what to include, but how to approach and show and how much background, how far can we go, what kind of evidence we need to gather ... these are the challenges."

When the writers arrived in the United States, one of their persistent worries was the way in which they might be asked to represent Latvians and Latvia in the context of the Holocaust, given the erroneous, yet oft-perceived, image of Latvians as Nazi apologists. During the first week of the project, the writers were, according to Amalija:

Very happy about many things, but one of our worries has been how people view Latvians and Latvia in the context of the Holocaust, and we heard from several presenters that there is nothing to worry about; these are just things that happened and there is no intention to blame. There is not attempt to blame and make big summaries. Everyone feels much better after these days. Instead of blaming and excoriating Latvians for collaboration or anti-Semitism, the lessons would instead "give teachers things that they can use; these are ready lessons with good materials and particular ideas of how to organize the lesson, evaluate, and understand in a precise way." Amalija was quite "glad that these materials are not as bloody and dark as previous materials. I hope this is accurate, where things have not been made too nice or simple. Still, it is not as depressing as previous ones available to teachers."
Through deliberative processes, the writers agreed to confront their controversial history. They envisioned the outcome of lessons in the teacher commonplace in a way that Latvian teachers would find appropriate and responsive to their experiences. At the end of the writing process, I asked the writers if their earlier concerns about the curriculum "blaming Latvians" were assuaged or enhanced. Klaudija felt that her "lessons don't touch that question and I think the rest of the group don't touch them either." Her focus was not on the Latvian role as collaborator or bystander but rather on the motivations of collaborators and bystanders. She went on to suggest that "I don't present data of Latvian collaborators, but I show the motivation that some chose to collaborate as they were afraid to be sent to the front or for labor." A year later she recapitulated her view that "my lessons, they don't blame Latvians. They neither blame nor defend, but in the lesson about bystanders there are citations about Latvian Jews saying not a single person spoke to protect us. All the Latvian politicians did nothing."

Amalija felt that "this idea about blaming Latvians was a concern about the reaction of the Latvian society. If we talk about the Holocaust, does that mean that someone blames Latvians?" Therefore, the final curriculum product mentioned Latvians who participated in executions, but "it doesn't talk very much about who is guilty." Rather, the curriculum's intention was to show "what happened and why. I believe this is a better approach." A small segment of society might think the curriculum "doesn't stress the guilt of Latvians, but I don't think we wanted that anyway." As a result, Amalija sought not to exclude the issue of collaboration but also not to emphasize individual guilt as a main goal.

The writers ultimately took an extremely controversial topic that, if dealt with incorrectly, could result in the demise of the project. By using a rational, reasoned, and informed approach, while simultaneously attending to the fears and concerns of the Latvian teachers, the writers neither avoided the issue of collaboration nor made the instances of collaboration the primary goal. Instead, the persistent focus throughout the curriculum concerned individuals and their choices, rather than emphasizing guilt and blame. During the field-testing phase of the project, Latvian teachers and students indicated strong approval not only for how the topic was treated but also for the array of meaningful and engaging instructional choices available throughout the curriculum. 


\section{Soviet Residue}

The educational system in the Soviet Union contained an ideological commitment that had little tolerance for any historical narrative outside the centrally controlled and state-approved uniform history (Wertsch, 2002). The method of curriculum deliberation is uniquely equipped to engage the underlying form of curriculum problems resulting from the Soviet period, including ideologies, community views, and political pressures, which can be unearthed and analyzed through a process of inquiry (Reid, 1999). The influence of Soviet residue on Holocaust education in Latvia became visible during the writers' work, and it helped inform their attention to instructional strategies in their lessons and teacher trainings as responses to this influence. The curriculum writers thought of Latvian teachers and their fears, foibles, needs, and hesitations as they crafted their curriculum. But they also considered the teacher commonplace as situated within the historical residue of the Soviet Union. When I spoke to Irina, who works at a historical museum in Latvia, she offered a number of insights pertaining to the Soviet influence on teachers:

A sad thing it is that a lot of [the teachers] are very old. Half of the regional representatives are at the age of retirement. I was teaching with my grandmass colleague, for example; can you imagine that? My grandma died some twenty years ago, and still her colleague is working. This older generationsome of them are open-minded and willing to learn; this is impressive. But sometimes you can also see something that is left over from Soviet system. Those teachers who worked in Soviet system were approved by Communist Party; they had to be very careful about what they were saying. At the beginning, when I started at the museum with these teacher training programs, I heard this question, 'How is it correct to teach?' so many times. I got the impression that there is one correct way to do things, but I believe this attitude is decreasing. They would ask, 'which is the correct textbook?' This word 'correct' is allergic. They want to do this correctly.

To an extent, the Soviet patterns of value were even at work in the deliberative writing process. Amalija indicated the lack of comfort among Latvians in discussing competing ideas, as they "have no experience in this." Rather, she indicated that the default setting of writers and teachers was that they "just wanted to be told what to do. They seek authority figures and try to please them and care not of the opinions of colleagues."
Soviet residue ultimately influenced the writing process in three main ways. First, the origins of the practical problem are rooted in the Soviet-imposed silence concerning the Holocaust in Latvia. Second, many teachers formed habits during the Soviet era, including the acquiescence to imposition of authority and control in their classrooms. As a result, many teachers have traditionally tended toward direct instruction and a fidelity approach to curriculum. Finally, in their work, the writing group also expressed Soviet vestiges in their initial silence and obsequiousness. At first, favoring the opinions and advice of the curriculum chairpersons hampered the deliberative spirit within the group. All three of these influences influenced the way in which the writers constructed the curriculum, including the decisions to write lessons rather than resource books and to avoid the extremes of flexibility and choice in their final product.

\section{Limited Time}

Perhaps the most prominent limitation of this cross-cultural curriculum deliberation experience was time. Time influenced the process of decision making in the project, as well as the perceived response to the role of time in Holocaust education in Latvia. In some ways, time constraints can benefit deliberative curriculum writing. McCutcheon (1995) suggested that knowing and acting within time constraints forces action. Time constraints can also deleteriously affect deliberation, and one of the main disadvantages of the deliberative method is its time-intensive nature (Herod, 2001). For example, perceiving a lack of time can lead to stress, an impediment of deliberation (McCutcheon, 1995). Also, Dewey (1922) noted that making decisions without proper time allotments is a reflective vice, similar to what Roby (1985, p. 21) called the "rush to the solution," which often comes about when writers perceive a crisis. Because deliberation is more likely to occur in "situations where there is consciousness of the need to justify decisions in general terms, and where group members are in sufficiently prolonged contact to be able to engage in the discovery process" (Reid, 1999, p. 29), a balance of brevity and prolongation is required.

An additional challenge resulting from the compressed timeline of the project included few opportunities for the writers to have plenary discussions about what they learned and how their new knowledge might influence subsequent lesson construction. For example, after the week at the USHMM, Amalija indicated that several team members had "become different people" as a result of the experience, but that "we haven't had time to discuss it, really, to see what we should use from this for the curriculum." 
In addition, some writers expressed moments of jealousy when one curriculum subgroup appeared to have more time to discuss issues for a segment of writing than the other. Jana remarked that "the other group spends one or two days and they are ready. We spend much more time and effort. And we haven't time to do anything else." Others complained that the "long nights [of working] were too much" and that no one has any complaints "except for [not having] enough time." Jana and Dagnija both recalled that, at the USHMM, they had "so many ideas, but we haven't time to tell to others what I think and what we want to do. There has been no time to speak as a group about this."

\section{Conclusion}

By heavily relying on teacher membership within the writing group, the project placed the burden of the practical curriculum problem on teachers (Schwab, 1983). But the project also recruited venerable historians, domestically and abroad, as well as respected teachers of the Holocaust and pedagogical experts. This congregation of talent led to the confluence of the best evidence in both democratic methods of teaching and Holocaust history, which provided variance of alternative ideas - a critical component of curriculum deliberation (McCutcheon, 1995; Schwab, 1970). Due to the project's cross-cultural structure, the writing team was positioned to reflect on the representation of different commonplaces, including teachers, students, subject matter, and the milieu. In addition, the international nature of the project resulted in a ceding of power from the curriculum chairmen, as the recruitment and selection of writers for the group was decided by the Latvian codirector.

The decision to hold much of the curriculum project outside of Latvia had great significance for how team members addressed the influences on Holocaust education in Latvia. Given the problems associated with the intrusion of status and power influencing participation and decisions within deliberation (Parker, 2003), writing curriculum in neutral and safe terrain allowed the project to unfold in a rational and democratic way that provided the writers with an opportunity to temporarily view their problem as outsiders, given the geographical, political, and intellectual distance from Latvia. Holding the writing process abroad resulted in largely unencumbered empowerment, autonomy, and liberation and disrupted the cultural tendency toward silence. In addition, the organization of the project was free from any specific charges or mandates from the funding agencies, bringing forth a sense of freedom among the writing team that had broad implications for their curricular choices. As a result of prolonged time in the United States, the curriculum writers were ultimately willing to awaken the Holocaust in Latvia and address contemporary prejudices, intolerance, xenophobia, and racism rooted in sustained silences of the Holocaust in Latvia.

Because the project paid particular attention to the recruitment of the writing team and the formation of deliberative experiences that honored the knowledge of Latvian teachers, the way in which writers made decisions flowed from that structure. Organizing writing experiences that allowed the final product to be of, by, and for Latvians was predicated on the latent open-mindedness of the writing team. This variant of curriculum deliberation included attention to commonplaces and the envisioning of consequences. Most importantly, it resulted in the production of lessons and completion of work within a set time frame, which can often be illusory within deliberation (Atkins, 1990). The structure of the project balanced the costs of producing numerous lessons, which include giving short shrift to deliberation and needing to provide teachers with substantive choices through an abundance of lesson plans. Achieving a balance in this regard stands out as a critical point when pondering the success of the project in terms of implementation.

Given the writing team's interest in implementation, they deliberatively constructed student-centered lessons so that teachers could cede some of their hesitancy to broach Holocaust issues with their students, which many writers thought would advance enactment and produce collateral democratic outcomes. The writers also determined that by including innovative instructional strategies, their lessons would be more promising in terms of implementation. Because teachers often act as gatekeepers to content, the writers determined that they had to privilege teachers as the primary fountainhead of their decisions. Although there is a danger of teachers writing curriculum for other teachers, in terms of perpetuating the status quo and relying on what teachers already do to inform their decisions (Schwab, 1973), the selection of progressive, open-minded, and thoughtful writers resulted in more reflective consideration. In addition, by structuring a substantive field test of the curriculum, other Latvian teachers and students were able to suggest revisions and alterations to the lesson plans. The recruitment of Latvia's most prominent Holocaust historians and members of various institutions of the milieu helped to insure that the curriculum was organically conceived within the unique context of Latvian society yet drew on the best available content, approaches, and ideas found abroad.

Some Latvian teachers still operate within a Soviet educational paradigm and tend toward a fidelity approach to instruction, while others are more democratically orient- 
ed. Knowing the diversity of Latvian teachers in terms of pedagogical and historical acuity, the writers decided to find a balance between calling on teacher judgment and rigid lessons that would inhibit instructional authority of the teacher, flexibility, and choice. Because the writers situated many of the lessons within a democratic context, the responses writers envisioned, such as "we are not Jews; why do we talk about Jews?" were largely negated. Similar to the balance found between the amount of deliberation and the number of lessons produced, the writers also alighted upon a balance between comfort and discomfort for their intended audience. Their attention to the educational situation that gave rise to the practical problem informed numerous decisions that were congruous with an end view of teacher implementation.

Throughout the writing process, the work of the group demonstrated the tradeoffs at work in curriculum writing. They avoided the extreme of protracted reflection but were also able to complete their goal. Some lessons focused on fitting within the 40-minute Latvian class restriction, while others erred on the side of historical explication. But curriculum deliberation and raising the question of "what should be done?" early in the project allowed the reasoning of the writing team to take its course through diverse perspectives and evidence. There is no such thing as the "perfect" or "best" way to devise curriculum (Walker, 1975), but the considerations of stakeholders provided collateral benefits for solving this particular problem, as the insertion of democratic methods helped to energize pedagogy in nonHolocaust lessons and active citizenship.

Given the mixed results of Holocaust education in other countries that experienced Nazi occupation or the Holocaust (Frankl, 2003; Santerini, 2003; van Driel 2003), it is remarkable that the Latvian curriculum writers, using cross-cultural deliberative methods, made significant headway in less than one year. In addition, the content that the Latvians chose to include not only was responsive to Schwabian commonplaces (Schwab, 1973) but also was historically rich, lacked monolithic depictions, contained eclectic sources, avoided generalizations, and was consonant with methods that do not diminish or undermine the singularity and uniqueness of the Holocaust (Burtonwood, 2002; Schweber, 2004; Totten, 2000; Totten \& Riley, 2005).

\section{Policy Implications}

This project demonstrated the promise of cross-cultural curriculum deliberation methods in responding to a silenced history and contemporary controversial issues by attending to the wide variety of stakeholders and institutions that have an interest in the development of historical narratives. The use of curriculum deliberation resulted in a number of positive outcomes for democratic citizenship, including accurate and inviting lessons, broaching controversial issues, the use of democratic teaching strategies, and the subjection of beliefs and attitudes to reconsideration, which can help reduce prejudices, intolerance, and racist attitudes. In sum, the findings of this study correspond to six policy recommendations for future curriculum projects of this kind:

1. Curriculum Deliberation: Controversial topics and silenced histories are embedded in particular cultures and contexts that have unique educational goals, histories, and problems. By establishing a group form of reflection and protracted consideration, writers can consider diverse stakeholders, normative forces, impediments, and the anticipated consequences of curricular decisions.

2. Local Teachers as Curriculum Writers: Only teachers from the particular culture that houses the curriculum problem have a deep understanding of the students, subject matter, teachers, and milieu. By positioning teachers from that society to consider these particularities, a responsive and practical curriculum can arise and enjoy implementation.

3. Cross-cultural Structure: Given the numerous jobs and limited time teachers in many societies have, as well as the politicized nature of controversial topics, holding curriculum writing sessions on neutral ground can help promote the consideration of the best available evidence concerning content and instructional strategies.

4. International Involvement: Curriculum planning teams can considerably improve curricula and help them gain cachet, visibility, and unity among international institutions by recruiting prominent educational leaders, curricularists, and topical experts.

5. Involvement of Local Institutions: Projects that develop new curricula in order to change current instructional gaps need to consult the appropriate teacher organizations, ministries of education, and political leaders. Rather than simply informing these groups of what will be done, projects should forge partnerships and collaborative arrangements that will enhance responsiveness and implementation.

6. Teacher Training: Given the number of impediments teachers face with new curricula, substantial efforts need to be made to involve teachers 
from diverse regions to participate in training events. As much as possible, these events should be coordinated with educational officials to promote and offer sufficient incentives for a wide variety and large number of teacher participants.

As societies avoid historical and contemporary controversies in their curriculum, students are often exposed to purported narratives of their nation that delimit beliefs and entrench singular narratives (Hein \& Selden, 2000). Because curriculum constitutes a normative anchor within the citizenry, the degree to which controversy and closed areas are exposed to rational consideration has profound implications for the vibrancy of a democracy. Cross-cultural curriculum deliberation is well suited to respond to these significant challenges while attending to diverse stakeholders and advancing active, thoughtful, and responsible citizenship.

\section{References}

Atkins, E. (1990). From competing paradigms to final consensus: A case study of the deliberations of a conflictprone curriculum group. Journal of Curriculum and Supervision, 5(4), 308-327.

Baum, R. N. (2000). Never to forget: Pedagogical memory and second-generation witness. In R. I. Simon, R. Rosenberg, \& C. Eppert (Eds.), Between hope \& despair (pp. 91-116). New York: Rowman \& Littlefield.

Bonser, S. A. \& Grundy, S. J. (1988). Reflective deliberation in the formulation of a school curriculum policy. Journal of Curriculum Studies, 20(1), 35-45.

Burtonwood, N. (2002). Holocaust memorial day in schools - context, process, and content: A review of research into Holocaust education. Educational Research, 44(1), 69-82.

Cohen, J. (1999). Deliberation, tradition, and the problem of incommensurability: Philosophical reflections on curriculum decision making. Educational Theory, 49(1), 71-89.

Deckert-Peaceman, H. (2003). Teaching the Holocaust in the USA: A German perspective. Intercultural Education, 14(2), 215-224.

Dewey, J. (1922). Human nature and conduct. New York: Henry Holt and Company.

Dewey, J. (1933). How we think. Lexington, MA: D.C. Heath $\&$ Company.

Engle, S. H., \& Ochoa, A. S. (1988). Education for democratic citizenship: Decision making in the social studies. New York: Teachers College Press.
Evans, R. W., Avery, P. G., \& Pederson, P. V. (2000). Taboo topics: Cultural restraint on teaching social issues. The Clearing House, 73(5), 295-302.

Fetterman, D. M. (1998). Ethnography. Thousand Oaks, CA: Sage.

Frankl, M. (2003). Holocaust education in the Czech Republic, 1989-2002. Intercultural Education, 14(2), 177189.

Glaser, B. G., \& Strauss, A. L. (1967). The discovery of grounded theory. Chicago: Aldine.

Griffin, A. F. (1942/1996). Teaching in authoritarian and democratic states, in W. C. Parker (Ed.), Educating the democratic mind (pp. 79-93). Albany: State University of New York Press. (Original work published 1942)

Hammersley, M., \& Atkinson, P. (1995). Ethnography. New York: Routledge.

Harris, I. B. (1986). Communicating the character of 'deliberation.' Journal of Curriculum Studies, 18(2), 115-132.

Harwood, A. M., \& Hahn, C. L. (1990). Controversial issues in the classroom. Bloomington, IN: Eric Clearinghouse for Social Studies Education. (ERIC Document Reproduction Service No. ED327453).

Hein, L., \& Selden, M. (2000). The lessons of war, global power, and social change. In L. Hein \& M. Selden (Eds.), Censoring history: Citizenship and memory in Japan, Germany, and the United States (pp. 3-52). New York: M. E. Sharpe.

Herod, L. (2001). Computers in adult literacy: The need for curriculum deliberation. New Horizons in Adult Education, 15(1), 15-22.

LaCapra, D. (1992). Representing the Holocaust: Reflections on the historians' debate. In S. Friedlander (Ed.), Probing the limits of representation (pp. 108-127). Cambridge: Harvard University Press.

Latvian Ministry of Education. (2004). Social studies: Exemplary program for basic education. Riga, Latvia: Ministry of Education Curriculum Development Center.

LeCompte, M. D., \& Schensul, J. J. (1999). Designing and conducting ethnographic research. Walnut Creek, CA: AltaMira.

Marker, G., \& Mehlinger, H. (1992). Social studies. In P. W. Jackson (Ed.), Handbook of research on curriculum (pp. 830-851). New York: MacMillan.

McCutcheon, G. (1995). Developing the curriculum: Solo and group deliberation. White Plains, NY: Longman Publishers. 
Merriam, S. B. (2001). Qualitative research and case study applications in education. San Francisco, CA: JosseyBass.

Miles, M. B., \& Huberman, A. M. (1994). Qualitative data analysis. Thousand Oaks, CA: Sage.

Mulder, M. (1991). Deliberation in curriculum conferences. Journal of Curriculum and Supervision, 6(4), 325-339.]

Parker, W. C. (2003). The deliberative approach to education for democracy: Problems and possibilities. In J. J. Patrick, G. E. Hamot, \& R. S. Leming (Eds.), Civic learning in teacher education (pp. 99-115). Bloomington, IN: Eric Clearinghouse.

Patton, M. Q. (1990). Qualitative evaluation and research methods. Newbury Park, CA: Sage.

Reid, W. (1999). Curriculum as institution and practice. Mahwah, NJ: Lawrence Erlbaum Associates.

Roby, T. W. (1985). Habits impeding deliberation. Journal of Curriculum Studies, 17(1), 17-35.

Ross, E. W., \& Marker, P. M. (2005). (If social studies is wrong) I don't want to be right. Theory and Research in Social Education, 33(1), 142-151.

Santerini, M. (2003). Holocaust education in Italy. Intercultural Education, 14(2), 225-232.

Schwab, J. J. (1970). The practical: A language for curriculum. In I. Westbury \& N. J. Wilkof (Eds.), Science, curriculum, and liberal education (pp. 287-321). Chicago: University of Chicago Press.

Schwab, J. J. (1971). The practical: Arts of eclectic. In I. Westbury \& N. J. Wilkof (Eds.), Science, curriculum, and liberal education (pp. 322-364). Chicago: University of Chicago Press.

Schwab, J. J. (1973). The practical: Translation into curriculum. In I. Westbury \& N. J. Wilkof (Eds.), Science, curriculum, and liberal education (pp. 365-383). Chicago: University of Chicago Press.

Schwab, J. J. (1975). Foreword. In W. A. Reid \& D. F. Walker (Eds.), Case studies in curriculum change (pp. vii-viii). Boston: Routledge \& Kegan Paul.

Schwab, J. J. (1983). The practical 4: Something for curriculum professors to do. In I. Westbury \& N. J. Wilkof (Eds.), Science, curriculum, and liberal education (pp. 239-265). Chicago: University of Chicago Press.

Schweber, S. (2004). Making sense of the Holocaust. New York: Teachers College Press.

Shaw, K. E. (1975). Negotiating curriculum change in a college of education. In W. A. Reid \& D. F. Walker (Eds.), Case studies in curriculum change (pp. 54-90). Boston: Routledge \& Kegan Paul.
Silva, D. Y. (2000). Collaborative curriculum encounters. Journal of Curriculum and Supervision, 15(4), 279-302. Simon, R. I. (2000). The paradoxical practice of zakhor: Memories of "what has never been my fault or my deed." In R. I. Simon, R. Rosenberg, \& C. Eppert (Eds.), Between hope \& despair (pp. 9-26). New York: Rowman \& Littlefield.

Totten, S. (2000). Teaching the Holocaust in the United States. In I. Davies (Ed.), Teaching the Holocaust: Educational dimensions, principles and practices (pp. 93104). New York: Continuum.

Totten, S., \& Feinberg, S. (1995). Teaching about the Holocaust: Rationale, content, methodology, \& resources. Social Education, 59(6), 323-333.

Totten, S., \& Riley, K. L. (2005). Authentic pedagogy and the Holocaust: A critical review of state sponsored Holocaust curricula. Theory and Research in Social Education, 33(1), 120-141.

van Driel, B. (2003). Some reflections on the connection between Holocaust education and intercultural education. Intercultural Education, 14(2), 125-137.

Walker, D. F. (1975). Curriculum development in an art project. In W. A. Reid \& D. F. Walker (Eds.), Case studies in curriculum change (pp. 91-135). Boston: Routledge $\&$ Kegan Paul.

Wertsch, J. V. (2002). Voices of collective remembering. New York: Cambridge University Press.

Wolcott, H. F. (1999). Ethnography: A way of seeing. Walnut Creek, CA: AltaMira. 